\title{
Tazkiyatun Nafs as an Effort to Reduce Premarital Sexual Behavior of Adolescents
}

\author{
Sri Hartati \\ Institut Agama Islam Ma'arif NU (IAIMNU) Metro, Indonesia \\ @ srihartati2191@gmail.com
}

Article Information:

Received January 30, 2018

Revised January 30, 2018

Accepted January 30, 2018

Keywords: Tazkiyatun Nafs, Premarital Sexual Behavior.

\begin{abstract}
This article describes the concept of tazkiyatun nafs as an effort to reduce premarital sexual behavior of adolescents. Tazkiyatun nafs is assistance provision process that directed, sustained and systematic to individuals in order to develop self-potential optimally through continuous purification of the soul to suppress the bad tendency and develop a good nature to get closer to Allah subhanahu wa ta'ala. This research is focus group discussion type. The results of research stated that tazkiyatun nafs which is used namely ma'rifah, mujahadah, riyadhah and muhasabah. Premarital sexual behavior can result in self-destructive. This can be minimized through the change of rational thinking of individuals who will be aware of the consequences of actions and control of their emotional impulses. People who can control themselves tend to keep away from premarital sexual behavior that is included in the act of adultery. Through tazkiyatun nafs counselees are expected to build ethical behavior as a servant of Allah as well as the khalifah of Allah and able to evaluate the behaviors that are less appropriate through learning to be responsible for what they do which include the consequences of the choices and actions.
\end{abstract}

\section{INTRODUCTION}

Adolescents are in a period that involves them to learn new ways of thinking and behaving that can narrow down their views and limit their choices. According to Hurlock, in this case, adolescents experience a period of transition from childhood to adult life (Hurlock, 2007). In the transitional period, it is possible to generate a crisis period, which is marked by the tendency of behavioral emergence that is not in accordance with the norms of religion and society. These changes have an impact on behavioral changes in adolescents. The most interesting discussion about adolescents' behavior which is discussed among the people, namely the issue of sexuality. The number of teenagers who have had sexual intercourse before marriage becomes a serious thought for parents, society, educators, clerics and even teenagers themselves (Mayasari, 2000)

The case of adolescents who have sexual intercourse is a problem that often occurs because according to one phase of adolescent development is a change in sexual interest. Adolescence is a phase of development between childhood and adulthood, between the ages of 12 and 21. Adolescence consists of early adolescence between 12-15 years old, middle adolescence between 15-18 years old, and late adolescence between18-21 years old. This period has begin the changes of sexual organ (Monks \& Haditomo, 2002).

Islamic law has a prohibition for its adherents in approaching the behavior of adultery. This is because premarital sexual behavior has a negative impact such as reducing productivity and the development of sexually transmitted diseases. However, the current fact

How to cite :

E-ISSN:

Published by:

Available Online:
Hartati, S. (2018). Tazkiyatun Nafs as an Effort to Reduce Premarital Sexual Behavior of Adolescents. Islamic Guidance and Counseling Journal, 1(1), 33-44. https://doi.org/10.25217/igcj.v1i1.207

2614-1566

Institut Agama Islam Ma'arif NU (IAIMNU) Metro Lampung

https://journal.iaimnumetrolampung.ac.id/index.php/igcj 
shows that the prohibition in Islam is increasingly marginalized which is caused by the flow of globalization.

Indeed, human beings are the most perfect creation of Allah. The perfection is a combination of body and spirit with a tendency to do good and to do evil (R. H. dkk, 2010). Through reason and spirit, a human can know what is good in human life. Lust and human weakness are illnesses that no human will survive these illnesses except through the exposure of revelation (Hawwa, 2002).

Based on the above, the teachings of Islam have provided many alternatives in providing therapy to premarital sexual behavior of adolescents for example by increasing understanding of religion (Aini, 2011). Because it is so important for the role of this religion for a person, it is not surprising that a British historian, Arnold Toynbee stated that the crisis experienced by modern Europeans was caused by spiritual poverty, while the path of healing exist in religion (Masbukin, 2003). Therefore, tazkiyatun nafs has an important role in filling the hearts and souls of human beings with positive emotions, so as to achieve ihsan level (Hartati, 2017). The attainment of the tazkiyatun nafs method in this paper is that the individual is able to balance between the forces that exist within the self including the body, soul, and spirit in thinking towards the realm of evaluating the emotions and behavior when a situation affects (Hartati, 2017).

\section{METHOD}

The nature of this research is descriptive-analysis by describing systematically all the concepts that have relevance to the discussion. Then, the author analyzes the appropriate data were collected. This research uses Focus Group Discussion (FGD) approach. The purpose of the FGD is to explore a specific problem related to the topic being discussed. This approach is used with the aim of avoiding the erroneous meaning of the author interpretations about the issues raised in this article. To analyze the obtained data, the author uses content analysis method. Content analysis method conducts a deep description of content, written information or printed in mass media (Arikunto, 2006)

\section{RESULT AND DISCUSSION}

\section{Tazkiyatun Nafs}

Tazkiyatun nafs comes from the word "tazkiyatun" which etymologically means to purify or cleanse, some scholars interpret it as to grow bigger and more (Hawwa, 2002). While the word nafs can be interpreted as the soul (QS. Al-fajr: 27-30), life (QS. Ali-Imran: 185), and lust (QS. Yusuf: 53). While the scholars interpret it as a force or ego (Asy`arie, 2002).

Nafs or soul has four terms that serve as a basic definition, namely, al-`aql, al-qalb, alnafs and al-ruh. First, Aql is always concerned with ethics and behavior that gives a sense that by rational thinking the individual will be aware of the consequences of the actions and control of emotional impulses in view of future (Abdullah, 2002).

Secondly, qalb according to Jalaluddin Rumi is a very wonderful thinking potential (Masharudin, 2002), because qalb serves as a driver and controller of other body parts. Third, the nafs is a subtle feeling (lathifah) that exists within the human soul and its substance, but may differ according to the spiritual condition of each (Auliya, 2005). The tendency of the nafs is to impose its desires in an attempt to satisfy oneself. While reason plays a limiting force as well as the advisor to the nafs, it gives consideration to the nafs about the positive actions that should be taken and the negative actions to be avoided. Fourth, the spirit is the subtle light in the human self by which human can know and feel as the function of the heart, and the spirit is the essence of the heart. 
Etymologically, Takziah has two meaning namely, sacred and growth (Hawwa, 1999). Tazkiyatun nafs perfection can be achieved with tazkiyatul aqli from a mischievous aqiqah and evil akhlak. While tazkiyatul aqli can also be achieved with pure monotheism (Ridha, 2007).

Sayyid Qutub in Tafsir Fi Dzilalil Quran, tazkiyatun nafs is the cleansing of the soul and feelings, purify the charity and sight, life and sex, and the society (Qutub, 1967). Muhammad Itris defined tazkiyatun nafs in Mu`jam Ta`biraat al-Quraniyah, by cleansing the souls of kufr and disobedience and improving oneself with righteous acts. It is done by improving the preparation of the good for the soul that defeats it for bad preparation for him (Itris, 1998). Moreover, Anas Ahmad Karzon argued that Tazkiyatun Nafs is to purify the soul from bad tendencies and sin and develop a good fitrah in it that can uphold istiqamah and reach ihsan level (Karzon, 2012).

Thus it can be concluded that tazkiyatun nafs is a process of soul purification continuously to suppress the bad tendency and develop a good fitrah to get closer to Allah subhanahu wa ta'ala.

Tazkiyatun nafs is closely related to the human effort to get closer to Allah. The basis of the argument, that Allah cannot be approached by people whose souls are impure because Allah is the Holy God, which can only be approached by the sacred person as well. Thus, the level of proximity (qurb), recognition (ma'rifat) and the level of love (mahabbat) of human towards him is dependent on the sanctity of the soul (Solihin, 2002).

Tazkiyah is meant as a way to fix a person from a low level to a higher level in terms of attitude, trait, personality, and character. The more humans do the tazkiyah on the personality traits, the more Allah takes them to a higher level. The word tazkiyatun nafs has definitions and ideas about: First, self-development efforts, namely the effort to realize human potentials into noble moral qualities (akhlakul hasanah). Second, self-purification efforts, namely the effort to guard against immoral tendencies (akhlakus sayyiah) (Effendi, 1991).

Thus, tazkiyatun nafs method in article is an assistance provision process that directed, sustained and systematic to individuals in order to develop self-potential optimally through continuous purification of the soul to suppress the bad tendency and develop a good nature to get closer to Allah subhanahu wa ta'ala.

\section{Dimension of Tazkiyatun Nafs}

Tazkiyatun nafs in the meaning of the purification of the soul includes all the efforts of the individual as a person who expects an encounter with his Lord. In the concept of the purification of the soul lays down several methods:

\section{Ma'rifah}

Ma'rifah is knowledge of religion nature secret, which is a higher science than science that commonly found by people in general (Saliba, 1979). Ma'rifah is knowledge whose object is not on things that are Zahir, but more deeply to the inner by knowing the secret. It is based on the view that human reason is able to know the nature of deity, and it is one, and everything comes from one (Saliba, 1979).

Ma'rifah is used to show on one level in Sufism. In this Sufistic sense, ma'rifah is defined as the science of God through the heart of the soul. Knowledge is so complete and clear that the soul feels united with that which knows, that is God (al-Kalabazi, 1969). The above opinion is in line with Nasution who described that ma'rifah is the relationship of meeting in the form of gnosis, knowledge with the heart of soul (Nasution, 1983).

From some definitions, it can be seen that ma'rifah is knowing the secrets of God by using the heart. Thus the goal to be achieved by this ma'rifah is to know the secrets of God.

\section{Mujahadah}

Mujahadah is etymologically derived from the word of Jahada, has the same root word as the word of Jihad, which means being earnest to arrive at the goal (M. dkk Ibrahim, n.d.). 
More broadly, mujahadah is a genuine effort to combat the lust (desire) and all sorts of personal ambitions so that the soul becomes pure clean as glass that can immediately grasp whatever is sacred, so it is entitled to obtain essential knowledge about Allah and His greatness.

Thus, the mujahadah is an act of resistance to lust, as it attempts to combat all the bad attitudes and behaviors inflicted by the lust of anger, commonly called as mujâhadah al-nafs (Suyuti, 1996). Related to that, Allah says;

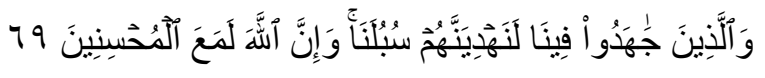

And (as for) those who strive hard for Us, We will most certainly guide them in Our ways; and Allah is most surely with the doers of good (Q.S. Al-Ankabut: 69).

Al-Ghazali likened human to a kingdom. Where the soul as the king, the territory is the body, as well as the senses and other limbs as the armies. Mind as vizier, as well as lust and the nature of anger as a police. The king and the vizier are always trying to bring human to a good path and be blessed by Allah. On the contrary, lust and anger always invite human into the path of misguided and wrathful. In order to create calm and happiness in the kingdom (human self), the power of kings and viziers must be above the power of lust and anger. If the opposite happened, the omen of the kingdom would collapse and perish (Al-Ghazali, 1980).

According to Al-Ghazali, the body is not the place of the soul because something that is jauhar (substance, matter, essence) does not inhabit a particular place. The body is a tool for the soul, while the body can not use the soul. Because the soul is baqa while the body is mortal (Al-Ghazali, 1980). We already know that treating body aches is to bring things together with their opponents. Similarly in heart illness. It is different for each individual because the character is different (Al-Ghazali, 2008).

\section{Muhasabah}

Muhasabah is to re-examine the heart, the oral deeds, and the other parts of the body (al-Yamani, 2012). Allah says:

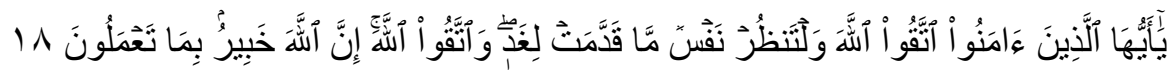

O you who believe! be careful of (your duty to) Allah, and let every soul consider what it has sent on for the morrow, and be careful of (your duty to) Allah; surely Allah is Aware of what you do (QS. Al-Hashr: 18).

Muhasabah (self-introspection) has two kinds, before worship and after worship. First, Muhasabah before worship that someone should pause, reflect on the first time the emergence of the desire to do something. Do not hurry until it is clear that doing it is better than leaving it (al-Yamani, 2012). Second, there are three kinds of muhasabah after the worship: first, selfintrospection of obedience that has been neglected, which is the right of Allah. That it has been done haphazardly, which is not proper. Though there are six rights of Allah associated with one form of obedience. That is, sincerity and loyal to Allah in it, follow the Prophet, witness it with ihsan witness, witnessed it as the grace of Allah, and witnessed the negligence in doing it. Second, self-introspection of every practice that better left out than performed. Third, self-examination of the mubah case, for what has done. The end of the neglected case, not accompanied by muhasabah, left alone, which is considered easy and trivial is destruction. This is the state of deceived people. They bury their eyes from the various consequences of their depravities while hoping Allah Subhanahu wa ta'ala forgive them. They never care about 
muhasabah and the consequences of their crime. Even if they do, they will immediately perform sin, pursue it and they will be very difficult to leave it (al-Yamani, 2012).

In conclusion of this description, someone should introspect on the obligatory things (fardhu). If they see any shortcomings to them, they will equip it with qadla '(replacement) or ishlah (improvement). Then on the things that are forbidden. If they feel they have ever perfomed it, they should immediately hasten to repent, pray, and practice good deeds that can take away sin. Then to the negligence. When they find themselves negligent of the purpose of creation, they should immediately recite dhikr and faces Allah SWT. Then to their utterances, or wherever their legs have walked, or whatever their hands have held, or whatever their ears have heard.

\section{Riyadhah}

Riyadhah means "practice". The point is spiritual practice to purify the soul by fighting the bodily desires. The process is performed by doing the cleaning or emptying the soul from everything other than Allah, then decorate the soul with dhikr, worship, godly worship and noble morals. The practice that included in the practice of riyadhah is to reduce food, reduce sleep to pray at night, avoid useless utterances, and seclusion that is to avoid association with the crowd to be filled with worship, in order to avoid the sin (Al-Ghazali, 2008).

Riyadhah al-nafs is how a person's efforts to become a person who has a noble character to avoid the bad characters and deeds. Rasulullah (Peace Be Upon Him) reminded that morality can be changed by action. So always try to subdue anger, lust and evil. All these traits are guidance from the shari'a. If doing so then the goal has been achieved. It is done with sincerity and patience over something that is hated so that after it becomes a habit (AlGhazali, 2008).

The purpose of riyadhah for a Sufi is to control oneself, both the soul and the body, in order to keep the spirit still pure (Asmaran, 1994). Therefore, riyadhah must be done in earnest and full of willingness. Riyadhah that is performed with sincerity can keep a person from making mistakes, either against humans or other creatures, especially against Allah. And for a Sufi, riyadhah is a means to go to the level of perfection, that is to attain the essence (Saifulloh, 1998).

One part of Sufism is riyadhah (worship practices). Riyadhah that is usually done namely, repent, to perform a repentance then it must be zuhud, wara', faqir, patience, tawakal, and ridha.

\section{Premarital Sexual Behavior of Adolescent}

Sexual behavior is all behavior that is driven by sexual desire, either with the opposite sex or with the opposite sex (Sarwono, 2016). Sexual behavior itself has a definition that is manifestation of the sexual urges that can be observed directly through the acts that are reflected in the stages of sexual behavior from the most mild to the most severe (Koentjoro, 2000). Similarly, Soetjiningsih stated that premarital adolescent sexual behavior as sexual behavior that is driven by sexual desire with the opposite sex which performed by teenagers before they get married (Soetjiningsih, 2008). Furthermore, according to Desmita, the definition of premarital sex is any means of expressing and releasing sexual urges from sexual organ maturity. Teenagers try to express it in various forms of sexual behavior from dating activities such as holding hands, kissing, making out until performing sexual contact (Desmita, 2012).

Based on some of the above opinions, it can be concluded that premarital sexual behavior is a manifestation of sexual urges expressed through all kinds of sexual acts such as dating, holding hands, kissing, until intercourse between two people with different sex without going through the process of legal marriage according to religion and belief of each individual. 
Premarital sexual behavior has a negative impact in weakening someone's faith and reducing teen productivity. In this case, Islam clearly forbids its adherents to stay away from adultery (Qs. Al-Israa: 32). However, according to the fact that currently, the ban on premarital sexual behavior has been increasingly marginalized and replaced freely in premarital sexual behavior.

Form of sexual behavior is the level of behavior performed by the opposite sex couple and the form of behavior is arranged based on the size of sexual satisfaction. Kinsey stated that there are four stages of sexual behavior: Touching, ranging from holding hands to hugging. Kissing, ranging from short kissing to kissing the lips. Petting, which is touching the sensitive part of the partner's body and leads to the rise of sexual desire and the sexual intercourse (IH, 1997).

Sexual desire becomes stronger when there is external stimulation both physical and psychological. Sarwono mentioned sexual behavior is influenced by several factors, namely: First, the increase of libido, in an effort to fill the social role, a teen gets motivated from the increase of sexual energy or libido, sexual energy is closely related to physical maturity (Sarwono, 2016). Second, Knowledge. Lack of knowledge about reproductive health in adolescents who have begun to develop sexual maturity completely, get less direction from parents about reproductive health, especially about the consequences of premarital sexual behavior then they are difficult to control the stimuli and many sexual opportunities of pornography through mass media that makes them conduct sexual behavior freely without knowing the risks that can occur such as unwanted pregnancies.

1) Information media. The presence of the spread of media information and sexual stimulation through mass media that is with the existence of sophisticated technologies such as, internet, magazines, television, video. Adolescents tend to want to know and want to try as well as want to imitate what they see and hear because the teenagers in general do not know the complete sexual problems from their parents. 2) Religion norms. While the marriage is postponed, religious norms remain in force where one should not engage in sexual intercourse before marriage. In modern society, the ban further develops at other levels such as kissing and masturbating for teenagers who can not resist the tendency to violate the ban. 3) Parents. Ignorance of parents and the attitude that is still taboo to conduct sex talks with children even tend to make a distance with children. As a result, the teenagers lack of knowledge about sexuality. Though the role of parents is very important, especially the provision of knowledge about sexuality. 4) Promiscuity. This phenomenon is prevalent in big cities, a lot of freedom in opposite sex relationships in adolescents, the higher the level of parental monitoring on adolescent, the lower the likelihood of deviant behavior on the teenagers (Sarwono, 2016).

According to research conducted by Suryoputro, the factors that influence adolescent sexual behavior in Central Java are, (a) internal factors (knowledge, aspects of reproductive health, attitudes toward sexual and reproductive health services, behaviors, perceived vulnerabilities to risk, reproductive health, lifestyle, self-control, social activities, confidence, age, religion, and marital status), (b) external factors (contact with information sources, family, socio-culture, values and norms as social support for certain behaviors) (Suryoputro, Ford, \& Shaluhiyah, 2006).

Another study explained the factors that influence sexual behavior namely: 1) Age. Physical development which include sexual organs that increase the reproductive hormone causes changes in teenage sexual behavior. The curiosity of adolescents on sexual problems is essential in establishing more mature relationships with the opposite sex. Explained by Bourgeois and Wolfish, in adolescence toward adulthood a person begins to feel clearly the increased sexual desire in self. It is characterized by the attraction with others with the desire to get sexual satisfaction (Hajar, 2015). 2) Gender. Biologically the development of female sexuality will be faster to be mature than male (Zulkifli, 1986). Most teenagers usually have 
developed sexual behavior with the opposite sex in the form of courtship or romance. The percentage of male adolescents who had a girlfriend was slightly higher than women (86.8 percent versus 83.7 percent). In expressing affection, 89.2 percent of adolescents were holding hands, 33.4 percent were kissing lips and 7.9 percent were petting or stimulating. Teenagers were asked whether ever had sexual intercourse. Based on the survey found that 4.2 percent of male adolescents and 1.1 percent of female adolescents have ever had sex (Junaidi, 2016)

Young men and women have different motivations on experience in dating. According to McMormick \& Jessor in Santrock explained that men follow a proactive date, while women follow reactive dating rules. The men's rules which include taking dates, controlling common things, and initiating sexual interactions. While the rules for women focused on the deep things and follow the dating plan that has been compiled by men, and respond to men's body movements that lead to sexual (Junaidi, 2016). This gender difference gives men a greater power in a relationship.

1) Permissiveness is defined as a more free attitude that can accept premarital sexual relations. The current trend is that teenagers are now more likely to be younger to have sex at the first time because of their greater sexual desire than in the past. Adolescence is considered as a period of experimenting with rules, roles and fellow relationships. The incessant display of sexuality is associated with a more permissive attitude toward premarital sex and recreational sex (Suarayasa, 2013). 2) Peer Influence, the influence of the environment in the first phase begins with the association with friends. At the age of 9-15 years, friendship is intimate relationship that is bound by the same interests, shared interests and sharing feelings, helping each other to solve common problems. Adolescents face the demand to form new and more mature relationships with the opposite sex. The search for identity and independence cause teenagers to spend more time with their peers (Maryatun, 2013).

\section{The Implementation of Tazkiyatun Nafs on Premarital Sexual Behavior}

Tazkiyatun nafs in this paper exist as an effort to help re-energize the potential within the individual human nature that has been given in the form of aql, qalb, nafs, and ruh (soul) and re-activate faith and piety until developed and functioned properly.

The soul in each individual is controlled by the aql and nafs both located within qalb. So that aql and nafs can live because of the spirit with the power of Allah. The human nature in the presence of Allah is shown through the human way of thinking rationally and realizing that human is the abdullah and khlalifatullah by observing all the commandments in the teachings of the Qur'an and Hadith and keep away from all forms of Allah's prohibition in order to obtain salvation in the world and the Hereafter.

In its application, the implementation of the tazkiyatun nafs method of premarital sexual behavior uses the stages in Rational Emotive Behavior Therapy (REBT) such as:

The first phase, the counselee is shown and made aware that they are illogical and irrational. This process helps the counselee understand how and why can be irrational. This stage provides an important role for the counselee to know his potential (ma'rifat). At this stage, the counselee is taught that they have the potential to change that. Secondly, at this stage, the counselee is helped to believe that negative thoughts and feelings can be challenged and changed. At this stage, the counselee explores ideas for determining rational objectives. Counselors also debate the counselee's irrational thoughts by using questions to oppose the validity of ideas about self, others, and the environment. At this stage, can be included dimension of mujahadah is used as an effort to combat the bad traits and behaviors caused by anger (Suyuti, 1996). The application of mujahadah dimension is by opposing irrational thoughts with challenging questions and replacing them into positive and rational thoughts and statements, and doing positive self-talk so as to produce more positive feelings and behaviors. Moreover, riyadhah is used as a form of effort to form a person who has a noble 
character (Al-Ghazali, 2008). In this stage, individuals train themselves to be able to stay away from the tendency of bad behavior which is premarital sex and fill it with commendable behavior. The third phase, in the final stage of the counsel, the counselee is assisted to continuously develop rational thoughts and develop a rational philosophy of life so that the counselee does not get stuck on problems caused by irrational thinking (Komalasari, 2014). So, in this case there is the role of muhasabah, muhasabah is used as an attempt to selfevaluate or introspect themselves on everything before and after work. In this case, muhasabah help individuals in changing irrational views that contain a way that is not logical in evaluating themselves, others and the surrounding environment (Komalasari, 2014). So through muhasabah, individuals are helped to restore the human nature as the khalifah of Allah (Khafidz, 2016).

Through tazkiyatun nafs counselees are expected to build ethical behavior as a servant of Allah as well as the khalifah of Allah and able to evaluate the behaviors that are less appropriate through learning to be responsible for what they do which include the consequences of the choices and actions.

\section{The Need of Tazkiyatun Nafs on The Decrease of Premarital Sexual Behavior}

Adolescents experience increased interest and motivation on sexuality (Desmita, 2012). The increased interest of adolescent on sexual interest is influenced by maturity factors of sexual organs and hormonal changes that result in the emergence of sexual desire in adolescents. To release the amount of sexual desire, adolescents try to express it in various forms of sexual behavior by dating activities such as holding hands, kissing, making out until performing sexual contact.

This is related to premarital sexual behavior of adolescents these days, in which there is expression of puberty, sexual desire and social relations needs, lifestyle and high curiosity as well as role models, to be recognized (Cholil, 2013). Premarital sexual behavior is any form of behavior that is driven by sexual desire (Sarwono, 2016).

The above phrase identifies that in conducting such behavior they still see that the norms which prevail in society do not match what they do. So they choose a place that they considered "safe" from the knowledge of the community. So ultimately, premarital sex behavior that is performed affects the psychological as mentioned by Mu'tadin namely guilt, irritability, excessive depression and cause aggression (Hajar, 2015).

Sexual behavior can also have an impact on society as a result of being expelled for being exposed to have sex before marriage. In addition, the impact of premarital sex also leads to an increase in cases of sexually transmitted diseases, especially HIV-AIDS, the still high mortality of young mothers, the spread of abortion practices due to unwanted pregnancies and the tendency of today's teenagers to have sex before marriage (Basuki, 2011).

Religion is necessary in controlling premarital sexual behavior. The level of religious understanding shows that the ability of adolescents to understand and know about religion. Therefore, the issue of religious commitment or religiosity is a very individual problem. Thus, adolescents desperately need to improve their faith and piety in accordance with their religion, because the understanding of religion that teenagers have can influence them in behaving.

In this case, tazkiyatun nafs has an important role as a human effort to get closer to Allah. As Sayyid Qutub had explained in the Fizalil Qur 'an that tazkiyatun nafs is the cleansing of soul and feeling, purifying the worship and outlook of life, cleansing life and sex relationships and cleansing the life of the community (Qutub, 1967).

Tazkiyatun nafs is an Islamic counseling approach that uses the principles of purification of the soul. Through tazkiyatun nafs, counselors strive to provide targeted, sustained and systematic assistance to individuals so that they can develop their potential optimally through continuous purification of the soul to suppress bad tendencies and develop a good fitrah to get closer to Allah. 
Hamjah's research showed that there are several aspects of spiritual guidance according to al-Ghazali that applied in counseling sessions, especially the concept of tazkiyah al-nafs. In that research results, there is a significant relationship between the spiritual guidance of alGhazali's perspective and the effectiveness of counseling. In addition, the results of the research also found that there are differences in the relationship factors with the tendency of counselors to apply al-Ghazali thought about spiritual guidance in counseling (Hamjah, 2010).

Similarly as Abdullah's research through "Model Taubat al-Ghazali (M-TaG)", he identified eight stages in the process of taubat al-Ghazali namely, the guidance of the belief, the guidance of sharia, moral guidance, taubat muhasabah, taubat muatabah (regret), taubat muaqabah, taubat mujahadah and istiqamah, significant acts to change in the process of repentance on the adulterers (S. Abdullah, 2014).

Arifin and Hamjah in their study of heart illness identified by counselors and applications of tazkiyah al-nafs through mujahadah al-nafs which include facing pressure, feelings of worry, sad and disappointed emotions and have hate and resentment feelings (Arifin \& Hamjah, 2017). Salleh and Khafidz also talked about the purification of the soul through the approach of muhasabah in the devotion of prayer as one of the spiritual cleaning process of a Muslim to achieve perfection of ubudiyah which confirmed in the Qur'an and alSunnah (Khafidz, 2016).

The process of soul purification is essential in encouraging a Muslim who can rid of bad and vile traits. Premarital sex behavior is a bad trait and included into the greatest lust of human beings (al-Yamani, 2012). This is because premarital sex behavior is the most powerful against reason when passion. Shahwat comes first in human rather than reason. If the mind is perfect and strong then reason will impale the lust and get rid of the habits and return the character by force to the pleased path of Allah.

Based on the above description, it can be concluded that premarital sexual behavior can result in self-destructive. This can be minimized through the change of rational thinking of individuals who will be aware of the consequences of actions and control of their emotional impulses. People who can control themselves tend to keep away from premarital sexual behavior that is included in the act of adultery.

\section{CONCLUSION}

Tazkiyatun nafs in this research was born as an effort to assist the counselee in the process of provision of assistance that is directed, sustainable and systematic so that he can develop his potential optimally through continuous purification of the soul to suppress the bad tendency and develop a good nature to get closer to Allah SWT. Tazkiyatun nafs used in it include ma'rifah, mujahadah, riyadhah, and muhasabah. Tazkiyatun nafs as a form of piety towards Allah SWT, so in the application of the concept tazkiyatun nafs aims to form a pure creed, sacred soul, knowledge and all activities of his life worth worship. Tazkiyatun nafs also form a holy soul and noble person in association and behavior toward his neighbor, who is aware of his rights and obligations so that his soul can be free from disgraceful behavior that can endanger him.

\section{REFERENCES}

Abdullah, M. A. (2002). Antara Al-Ghazali dan Kant: Filsafat Etika Islam. Bandung: Mizan.

Abdullah, S. (2014). Model Taubat al-Ghazali (M-TaG), Vol.13 (Special Edition) 2014.

Aini, L. N. (2011). Hubungan Tingkat Agama (Religiusitas) dengan Perilaku Seks Bebas pada Remaja di SMAN 1 Bangsal Mojokerto.

al-Yamani, S. Y. ibn H. (2012). Pelatihan Lengkap Tazkiyatun Nafs. Jakarta: Zaman. 
Al-Ghazali. (1980). Ihya Ulum Al-Din. Beirut: Dar al-Fikr.

Al-Ghazali. (2008). Mutiara Ihya 'Ulumuddin: Ringkasan yang Ditulis Oleh Sang Hujjatul Islam. Bandung: PT Mizan Pustaka.

al-Kalabazi. (1969). al-Ta'arruf li Mazhab ahl al-Tasawuf. Mesir: Dar al-Qohirah.

Arifin, S. N. A. M., \& Hamjah, S. H. (2017). Aplikasi Tazkiyah Al-Nafs Menerusi Mujahadah Al-Nafs dalam Kaunseling. Fikiran Masyarakat, 5(2), 57-61.

Arikunto, S. (2006). Prosedur Penelitian, Suatu Pendekatan Praktik. Jakarta: Rineka Cipta.

Asmaran. (1994). Pengantar Studi Tasawuf. Jakarta: PT Raja Grafindo Persada.

Asy`arie, M. (2002). Dialektika Agama untuk Pembebasan Spiritual. Yogyakarta: LESFI.

Auliya, M. Y. D. (2005). Melejitkan Kecerdasan Hati dan Otak. Jakarta: PT Raja Grafindo Persada.

Basuki, N. L. P. dan H. (2011). Hubungan Karakteristik Remaja Terkait Risiko Penularan HIV-AIDS dan Perilaku Seks Tidak Aman di Indonesia, Buletin Penelitian Sistem Kesehatan, Vol. 14 no. 4 oktober 2011.

Cholil, M. (2013). Psikologi keluarga Islam: Berwawasan gender. UIN-Maliki Press.

Desmita. (2012). Psikologi Perkembangan. Bandung: PT Remaja Rosda Karya.

dkk, M., Ibrahim,. (n.d.). Al-Mu'jam al-Wasîth, Al-Da'wah. Cacgri-Istanbul.

dkk, R. H. (2010). Spiritual Education Development Model, 1.

Effendi, D. (1991). Ulumul Quran (Vol. 2).

Hajar, R. P. (2015). Hubungan Antara Sikap Beragama dan Kecenderungan Perilaku Seksual Pranikah Pada Mahasiswa. UIN Sunan Kalijaga, Yogyakarta.

Hamjah, S. H. (2010). Bimbingan Spiritual menurut al-Ghazali dan Hubungannya dengan Keberkesanan Kaunseling: Satu Kajian di Pusat Kaunseling Majlis Agama Islam Negeri Sembilan (PK MAINS), ISL MIYY T32 (2010).

Hartati, S. (2017). Pengaruh Bimbingan dan Konseling Tazkiyatun Nafs dengan Pendekatan Rational Emotive Behavior Therapy terhadap Penurunan Perilaku Seksual Pranikah Remaja. UIN Sunan Kalijaga, Yogyakarta.

Hawwa, S. (1999). Mensucikan Jiwa: Konsep Tazkiyatun Nafs Terpadu. Jakarta: Robbani Press.

Hawwa, S. (2002). Al-Islâm. Jakarta: al-I'tishom.

Hurlock, E. B. (2007). Psikologi Perkembangan. Jakarta: Erlangga.

IH, F., A. \&. Martua. (1997). Seksualitas Remaja. Jakarta: Pustaka Sinar Harapan.

Itris, M. (1998). Mu`jam At-Ta`biraat Al-Quraniyah. Kairo: Dar As-Tsaqofah Lin-Nasyr.

Junaidi. (2016). Tinjauan Hasil Survai Indikator Kinerja RPJMN 2015 BKKBN Provinsi Jambi, disampaikan pada rapat Koordinasi BKKBN Provinsi Jambi.

Karzon, A. A. (2012). Tazkiyatun Nafs. Jakarta: Akbar Media.

Khafidz, N. S. K. N. S. dan H. A. (2016). Penyucian Jiwa Melalui Pendekatan Muhasabah dalam Penghayatan Shalat, Fikiran Masyarakat, ISSN: 2338-512X. Vol. 4, No. 2. 
Koentjoro, A. D. P. dan. (2000). Penyingkapan Diri, Perilaku Seksual, dan Penyalahgunaan Narkoba, Jurnal Psikologi, ISSN: 0215-8884. 2000, No 1.

Komalasari, G. (2014). Teori dan Teknik Konseling. Jakarta: PT Indeks.

Maryatun. (2013). Peran Teman Sebaya Terhadap Perilaku Seksual Pranikah Pada Remaja Di SMA Muhammadiyah 3 Surakarta, GASTER, Vol. 10 No. 1.

Masbukin, I. (2003). Rahasia Shalat bagi Penyembuhan Fisik dan Psikis. Yogyakarta: Mitra Pustaka.

Masharudin, A. S. dan. (2002). Intelektualisme Tasawuf. Yogyakarta: Pustaka Pelajar.

Mayasari, M. N. R. H. F. (2000). Perilaku Seksual Remaja Dalam Berpacaran Ditinjau Dari Harga Diri Berdasarkan Jenis Kelamin, No. 2, 120-127.

Nasution, H. (1983). Falsafah dan Mistisisme dalam Islam. Jakarta: Bulan Bintang.

Qutub, S. (1967). Tafsir Fi Dzalil Qur`An. Bairut Lubnan: Ihya Al-Turats Al-Farabi.

Ridha, M. R. (2007). Tafsir Al-Manar. Mesir: Maktabat Al-Qahirat.

Saifulloh, A. A., S. .. Moh. (1998). Risalah Memahami Ilmu Tasawuf. Surabaya: Terbit Terang.

Saliba, J. (1979). Mu'jam al-Falsafi. Beirut: Dar al-Kitab.

Sarwono, S. W. (2016). Psikologi Remaja. Jakarta: PT Raja Grafindo Persada.

Soetjiningsih, C. H. (2008). Faktor-faktor yang mempengaruhi perilaku seksual pranikah pada remaja.

Solihin, M. (2002). Kamus Tasawuf. Bandung: PT Remaja Rosda Karya.

Suarayasa, R. H. dan K. (2013). Perilaku Seksual Pranikah pada Siswa SMA Negeri 1 Palu, Jurnal Academica. Vol. 5 No. 02.

Suryoputro, A., Ford, N. J., \& Shaluhiyah, Z. (2006). Faktor-faktor yang mempengaruhi perilaku seksual remaja di jawa tengah: implikasinya terhadap kebijakan dan layanan kesehatan seksual dan reproduksi. Makara Kesehatan, 10(1), 29-40.

Suyuti, A. (1996). Percik-Percik Kesufian. Jakarta: Pustaka Amani.

Zulkifli. (1986). Psikologi Perkembangan. Bandung: Remadja Karya. 
